Article

\title{
Platform Party between Digital Activism and Hyper-Leadership: The Reshaping of the Public Sphere
}

\author{
Emiliana De Blasio ${ }^{1, *}$ and Lorenzo Viviani ${ }^{2}$ \\ ${ }^{1}$ Department of Political Science, LUISS University, 00197 Rome, Italy; E-Mail: edeblasio@luiss.it \\ 2 Department of Political Science, University of Pisa, 56126 Pisa, Italy; E-Mail: Iorenzo.viviani@unipi.it \\ * Corresponding author
}

Submitted: 5 May 2020 | Accepted: 19 June 2020 | Published: 8 October 2020

\begin{abstract}
The so-called crisis of representation has formed the theoretical framework of many studies on media and democracy of the past thirty years. Many researches have highlighted the crisis of legitimacy and credibility of the 'traditional' parties (Katz \& Mair, 2018) and communication was considered, at the same time, one of the causes of acceleration towards post-representative politics (Keane, 2013) but also an indispensable tool for re-connecting citizens to politics. Various phenomena have developed within this framework: a) the birth of political aggregations as a result of mobilization in the digital ecosystem; b) the development of digital platforms for democratic participation; $c$ ) the birth of parties defined as 'digital' or 'platform'; and d) the growing centrality of digital political activism, both as a phenomenon within the digital communicative ecosystem (also in the context of social media) and as a result of the transformation of social movements. This article studies the role of platform parties as a space for the emergence of authoritarian tendencies (hyper-leadership) but also as an organizational opportunity for the development of new forms of digital activism. In particular, the article presents a research on the use of digital platforms (and their political and organizational consequences) by political parties in Italy, France, and Spain. The study shows the relationships between the evolution of digital ecosystems and the way in which political organization is organised, also highlighting how the new forms of mobilization and aggregation have opened up different yet interconnected public spaces.
\end{abstract}

\section{Keywords}

digital activism; digital ecosystem; platform party; post-representative democracy; public sphere

Issue

This article is part of the issue "The Ongoing Transformation of the Digital Public Sphere" edited by Emiliana De Blasio (LUISS University, Italy), Marianne Kneuer (Hildesheim University, Germany), Wolf J. Schünemann (Hildesheim University, Germany) and Michele Sorice (LUISS University, Italy).

(C) 2020 by the authors; licensee Cogitatio (Lisbon, Portugal). This article is licensed under a Creative Commons Attribution 4.0 International License (CC BY).

\section{Introduction}

In this article, we try to highlight the relationships between the development of new organizational forms of politics (such as the so-called platform parties) and digital activism which, in turn, has intertwined both with forms of hyper-leadership (such as occurred in some forms of populism) with the emergence of reticular and horizontal political aggregations. The complex mutations involving the public sphere-to the point that the same expression seems to be declined with different mean- ings by different authors-are in turn closely interconnected with the now evident centrality of digital communication ecosystems. In this article, we started from the crisis (presumed but nevertheless strongly perceived) of the centrality of political parties in "post-representative politics" (Keane, 2009, 2013) which finds in the communicative ecosystems important actors for activating and speeding up that transformation. We then highlighted the evolution of plebiscitary appeal, closely connected both to the re-emergence of populisms and to the transformation of intermediate political bodies itself: The ten- 
dencies towards leadership, the substantial marginalization of activists and sympathizers, and even the development of authoritarian 'leaderism' are elements that distinguish this transformation. The cases of France, Italy, and Spain-despite their respective historical, cultural, and institutional peculiarities-constitute an important territory of analysis. In these countries, in fact, different (sometimes even contradictory) phenomena emerged which are located on the complex ridge of relations between populism, new forms of digital activism, and 'platformization' processes of the public sphere. The relationships between digital parties, platform parties, and networked parties-starting from the three countries analysed-constitute an important test for social and political research. In this scenario, the transformation of the public sphere is considered as a frame element that at the same time impacts the evolution of the political parties-and, more generally, the forms of mobilisation of politics-and is influenced by the transformation of the logic of representation.

\section{A Crisis of Party in Post-Representative Democracy?}

The repeated use of the term 'crisis of parties' is a key feature of the wider process of transformation of 20th century political forms and, in particular, the protest against the political representation proper of liberal democracies (Keane, 2009; Merkel, 2014, 2018; Tormey, 2015). The growing distrust of the role of political parties is part of the progressive overcoming of party democracy and the crisis of legitimising the forms of democracy in its 'minimal' and 'procedural' version, with the transition to an audience democracy that to a large extent recalls the Schumpeterian theory of democracy (Green, 2010; Körösényi \& Pakulski, 2012; Manin, 1997). Within this process of transforming democracy, plebiscitarism marks the overcoming of collective actors as intermediaries of democracy, in fact substantiating the democratic method in the mere possibility for voters to choose, and legitimise by voting, the leaders who govern them (Schumpeter, 2003). The challenges to the representation and role of political parties arise in discussion of the political representation proper to liberal democracies, opening the way for different developments of plebiscitarism, from leader democracy to the most radical forms of populist audience democracy (De Blasio \& Sorice, 2018; Urbinati, 2019). In the changing models of representation in the post 'party democracy era,' the electoral dimension alone does not guarantee the legitimacy of democracy but only enables the 'rule of the majority,' underestimating the forms of trust, identity, and political project which comprise democracy. Furthermore, consideration of the different evolutions undertaken by representative democracy has led to hypothesised transformations in which the plebiscite dimension undermines the very foundations of representative democracy, due to the transformation of the same procedural rule of the majority (Levitsky \& Ziblatt, 2018), highlighting the possibility of regression or rupture in democracy's path (Crouch, 2003; della Porta, 2013; Runciman, 2018). The rights of freedom, the rights of participation, the controls on power, the forms of self-government, and the horizontal accountability are in fact necessary conditions to avoid the transformation into defective democracy, in the various forms this can take, and particularly in predicting an illiberal populist democracy and ones with a technocratic or authoritarian nature (Merkel, 2004, 2018; Pappas, 2019). Starting from the de-freezing of traditional cleavage politics, after 1989, the 'hostile' climate towards political parties developed from divergent perspectives. On the one hand, the role of parties in advanced democracies has been contested for the benefit of a post-representative politics, where the intermediation of traditional forms of integration is opposed by a new protagonism from citizens. They do not limit themselves to the election period but monitor the work of institutions, up to taking on the character of a "counter-democracy" based on the power of control, veto, and judgement (Keane, 2009, 2013; Rosanvallon, 2008). On the other hand, parties as interpreters of the plural political conflict are instead challenged in the name of a 'holistic' conception of the political community that coincides with the 'majority,' in a perspective of "direct representation" that is typical of the populist version of democracy (Diehl, 2019; Müller, 2016; Urbinati, 2019). Instead of a rereading of society capable of interpreting and guiding the complexity of the transformation of democracy's social bases, the conditions are created for politicising dissatisfaction with democracy's 'unfulfilled promises.' These mainly concern the tension between democracy as 'an ideal' and democracy as 'a procedure,' the persistence of conflicting interests of multiple social groups instead of a 'monistic' people, the greater impact of the representation of interests compared to political representation, the failure to overcome the elite in representative democracy, the persistence of areas of social and political regulation which democracy has failed to enter, the role of invisible powers, and the presence of cronyism (Bobbio, 1984, pp. 7-8; Müller, 2016, pp. 62-63).

The problem of parties is therefore the broader problem of political representation, since while liberal democracy mainly develops its procedural aspect, the fact remains that governing and regulating do not amount to representing (Tormey, 2015, p. 79) and the perception of this disconnect feeds dissatisfaction with the actors of liberal democracy. On the one hand, there is no possibility of voting for the future, for a society with which people can identify and which legitimises the unequal distribution of power between the governing and the governed. On the other hand, in parallel, the established processes of personalising politics and leadership create the conditions which now result in people trusting new political entrepreneurs, leading outsiders who become the main 'confidants' of the masses and 'interpreters' of criticism of the political system and its establishment. The appear- 
ance of a crisis of representation involving political parties is not new in democracy's path and can occur in different cases within the relationship between modernisation and democratisation. During the transformation processes of societies and democracies, ruptures may arise as a result of unorganised masses entering the electoral circuit, in the presence of political and party systems crises, as part of a process of personalization of politics, and finally as a reaction to the cartel parties systems' weakened accountability and responsiveness and power without legitimacy (Roberts, 2015).

In late modernity societies, the progressive weakening of traditional intermediary organizations and the growing personalization of power accompany the processes of redefining the social bases of democracy, the institutional dynamics of redistributing regulatory power to supranational institutions, the multifaceted reality of globalisation, and the development of media influence. This creates the structure of opportunities for leaders and parties that challenge traditional party politics to emerge (Meny \& Surel, 2002, p. 21). In this scenario, can parties still be considered indispensable tools for democracy? Or is the political party the redundant burden of a system that has definitively embarked on the slippery slope of post-representation and post-democracy?

Mainstream parties' loss of relevance within the public sphere in advanced democracies (Dalton \& Wattenberg, 2000; Webb, Farrell, \& Holliday, 2002) can be interpreted as a 'crisis' only if the particular balance of organizational models and functions in the period of party democracy is taken as the paradigm for evaluating political forms. The vast empirical data on distrust of parties, the falling number of members, and the increased volatility of electoral choices confirm that the actor-party is irreversibly condemned to lose its central role on the political stage (Dalton, 2004; Mair, 2013; van Biezen, Mair, \& Poguntke, 2012). The categories underlying the phenomenology of the crisis of parties ultimately refer to the loss of expressive capacity for parties "without firm social roots" (Poguntke, 2002). The key feature of the debate refers to the changed relationship between citizens and parties, connected to the loss of trust and belonging generated by collective identity incentives. Participation in specific objectives, active involvement based on a system of individual values, and declining identification with parties constitute some of the most relevant challenges to representative democracy. Despite the crisis' broad phenomenology, it could be objected that to date there are no functional equivalents to parties in the capacity to structure political conflict and ensure that democracies function, and this decline actually refers to a type of organization-the mass integration party-while underestimating the capacity to adapt and transform (Dalton, Farrell, \& McAllister, 2011). The crisis of parties is therefore attributable to the more general compatibility of partisanship with the forms taken by post-representative democracy (White \& Ypi, 2016) and to parties' relevance in the contemporary public sphere regarding the type of functions performed and organizations adopted in transforming the linkage between politics and society.

\section{Plebiscitarian Politics and New Political Parties}

The relationship between the entities operating in postintegration mass democracies changes, enabling a public sphere to emerge that is no longer colonised by the logic of the party as the only pervasive actor. However, the party itself is part of a civil society ranging from the active role of individual citizens, to new social movements, to a wide range of voluntary non-state and non-economic associations, including the independent media itself (Cohen \& Arato, 1992; Habermas, 1990). In this re-opened public sphere, the party no longer holds its hegemonic role, let alone the monopolistic one of "gatekeeper" (Caramani, 2017, p. 59), and within it there also begins a process of differentiating the different intra-party faces comprising the organization (Gauja, 2017, p. 27).

The party becomes a network itself, divests some functions traditionally associated with its internal organization and geographical structuring by organizationalbureaucratic penetration, and maintains the formation of the ruling class, the selection of candidates, and the procedural-electoral part (Gunther \& Diamond, 2001). If these functions belong to the organization of the party proper, then there are also a series of associative realities which, though not expressly part of the party's institutional activities, nevertheless fall within the political network that shares a common process of political identification. The crisis of parties is, therefore, more properly a process of transforming the functions they perform in relation to the changing social bases of democracy and the greater relevance that individual political actors assume at the expense of parties and collective identities, with the changing behaviour of voters and elected officials within the political sphere (Karvonen, 2010). The relationship between personalization and politics not only refers to the relationship between voters and leaders but also involves the personalization of leadership and, in particular, the convergence between concentration of power and the relevance of the monocratic leadership within groups and institutions (Blondel \& Thiébault, 2010; Garzia, 2014). This phenomenon concerns the leader's autonomy from the party, both in the organizational hierarchy and as a representative of the ruling party, and, finally, the personalization of election campaigns, conducted on the basis of the leader candidate's choices and personality (Poguntke \& Webb, 2005). Not only, then, do the erosion of traditional cleavages and the new pervasiveness of mass communication create favourable conditions for disintermediating the relationship between voters and politicians but the entire institutional framework also favours the growth of the leader's role. The resulting process shifts accountability from the collegiate and collective dimension to the individual one, while public resources are simultane- 
ously made available to the leader to "invest" in building personal consensus (McAllister, 2007, p. 572; Rahat \& Kenig, 2018, p. 129). From the perspective of transforming democracy, these dynamics do not determine the end of political representation, because the personalization of top leadership continues to be embedded in a neo-elitist model of democracy. Here, the power of the elite is replaced by the power of the leader (Higley \& Pakulski, 2008; Pakulski, 2012) and the party becomes the tool of the leader (and not vice versa). In other words, it is a process which, starting from the catch-all party, confirms a common tendency for political systems and parties in advanced democracies whereby "the leaders become the party and the party is nothing but its leaders" (Katz \& Mair, 2002, p. 126). This democracy, however, remains exposed to the paradox of leader democracy, whereby the personalised leader can count on the legitimacy deriving from the disintermediated consensus, i.e., a growing plebiscitarian tie between leader and electors, but his power is simultaneously weakened by a lower capacity for regulation due to the lost primacy of politics when exercising decision-making power. This picture has radicalised since the 'Great Recession' in 2008, due to the scarcity of resources and the constraints imposed by austerity policies. It has led to national governments weakening further in terms of the nation-state's difficulty in coping with global economic and financial crises and the depoliticisation of spheres of public regulation, especially when attributing decision-making power to non-majority institutions (Raniolo \& Morlino, 2017). The picture that emerges is one of political systems where leaders are used up quickly, not only in the event of electoral defeat, but also when they manage to reach government positions. The plebiscitarianism inherent in personalization of top leadership is an expression of a transformed configuration of the political party with its power concentrated in the leader. Here, we can observe the transition from a labour-intensive to a capitalintensive mode (i.e., a decreasing role of membership and a growing role of professional staff in electoral campaigns), verticalized decision-making processes, the declining relevance of middle managers, increased financial resources directly available to the leader, and cronyism developing within the party due to non-top personalization within the organization, especially in locally elected parties (Ignazi, 2017; Musella, 2018). It is precisely in these transformation processes that tensions arise between the procedural dimension of democracy and the increased relevance, trust, and legitimacy borne by individual political interpreters. If, on the one hand, the conditions are created for personalised leadership and the transition from party democracy to forms of leader democracy, on the other hand the leadership tends to see its trust capital rapidly deteriorate. This typology includes different political forms and cannot be traced back solely to the personal party or the party of the charismatic leader (Blondel \& Thiébault, 2010; Viviani, 2017). Although the development trajectory of top lead- ership personalization is not unidirectional, some recurring variables act on it. In particular, it is necessary to consider the effects of the institutional set-up, i.e., all those rules, mechanisms, and institutions that shift centrality from parties to leaders, the effects of the mass media's role in the dual perspective of personalization as a focus on the activities of individual politicians and personalization as "media privatisation," i.e., a shift of attention to their extra-political characteristics, and, finally, the effects of the degree of personalization on political behaviour. This in fact corresponds to the more general personalization of politics, for both politicians and voters (Rahat \& Sheafer, 2007, pp. 66-68). In reinforcing personalization, not only do 'exogenous' variables act on parties, but their use of personalised leadership constitutes a 'strategy' implemented by mainstream parties to tackle the deficit of trust. They democratise the procedures for selecting the leader, as in the use of primaries, to counter the discredit and distrust of the political class with the relegitimisation of a leader chosen by a broader selectorate than the party oligarchies, extending participation to the entire potential electorate (Pilet \& Cross, 2015).

The prospect of a transition from party democracy to leader democracy calls into question the various forms plebiscite disintermediation can also take in the context of new political entities. Here, the organization of the filter between grassroots electors and membership and elected officials is overcome by substituting a leader who redefines the form of democratic representation and the forms themselves of the new parties. In fact, we are not dealing with a post-representative dimension of politics but are gradually moving away from the aggregation and articulation of interests typical of mass political parties to reach a system where the leader receives authorisation to govern, without the objective of 'representation' but with a free mandate that lets him create the people and move them in one direction, making leadership the very essence of representation (Körösényi, 2005, p. 377). In this sense, traditional political representation is transformed and the representative claim becomes increasingly important, i.e., that made directly by the leader (and the staff supporting his action), whose performance renders him the leading actor and not just a representative agent, moreover, with recognition that is not bound to a pre-established audience (Saward, 2010, pp. 66-67). In the transformation of parties, and even more so in digital parties, the leader plays a central in synthesising and symbolically expressing a social whole that is inherently fragmented and weakly institutionalised. In this sense, the hyper-leader of the digital parties makes use of disintermediation tools of the new and old media, conveying his image and acting as an "external object" that promotes the sense of community and makes bonds of solidarity possible between the group's real and virtual members (Gerbaudo, 2019 , pp. 146-147). It is, however, a question of distinguishing the processes of personalization as well as the forms that plebiscite disintermediation takes in the 
various challenges facing liberal democracy. On the one hand, as Mair (2002) proposes, the leader democracy cannot be identified as a partyless democracy, which in the name of directism goes beyond parties and produces anti-partyism as a relevant part of a political identity inevitably oriented towards the emergence of a populist model of representation and plebiscite democracy. On the other hand, the leader democracy continues to operate within a representative politics from a perspective of democratic elitism, with representation and delegation concentrated in the leader. Meanwhile, the "constituents," the voting citizens, remain "reactive," in that they can only play a role at election time or through the ability to exercise "eye" control (Green, 2010, p. $125)$, i.e., as spectator-judges able to observe politicians' behaviour via the media. In this context, the challenges to political representation emerge, now in the form of participatory and decision-making perspectives of democratisation of democracy in the various forms assumed by populism.

\section{Populism and Digital Movement Parties in France, Italy, and Spain}

In the transformation of advanced democracies, along with the erosion of traditional cleavage politics, a feeling of detachment, distrust, and opposition has gradually developed towards the political class and mainstream parties (Bornschier, 2010; Kriesi et al., 2012). This sentiment can take the form of apathy, with electoral abstention, and protest, with the birth of anti-establishment parties. Due to the ability of cartel parties to maintain institutional and government political 'dominance,' the challenge of a growing anti-establishment attitude has helped a large 'galaxy' of anti-political-establishment parties and populist anti-parties to emerge (Abedi, 2004; Mudde, 1996; Schedler, 1996; Viviani, 2019). The birth of these parties in European societies and democracies refers to the dynamics, on the one hand, of the transformation of mainstream parties into personalised catchall parties, progressively inserted within state institutions as "public utilities" (van Biezen, 2004) and, on the other hand, to the process which began in the 1960s and 1970s and created a plan for anti-establishment conflict with the new left's New Politics season, the new right's silent counter-revolution, and finally the emergence of New Populism following the 2008 economic crisis and the impacts of globalisation. This process has as its unitary matrix the political crisis of legitimising representative democracies but has nevertheless produced different outcomes not only between Western European democracies and Southern European democracies, but also within the same areas. In the three case studies examined-France, Spain, and Italy-the emergence of new parties responds to variables relating to the political system format, the type of political culture, the type of institutional system and electoral laws, and the effects of the economic crisis from 2008 on- wards (Kriesi \& Hutter, 2019; Kriesi \& Pappas, 2015). This results in different types of new parties, in particular: a) parties of the new populist right-Marine Le Pen's Front National, Matteo Salvini's League, and the Spanish party Vox; b) parties of the new populist left-Pablo Iglesias' Podemos and Jean-Luc Mélenchon's La France Insoumise; and c) anti-party parties like M5S, whose heterogeneous social bases give them the character of a "catch-all anti-party party" and "post-modern and postideological (non)party" (Bordignon \& Ceccarini, 2015; Ceccarini \& Bordignon, 2016). As regards the party transformation process and the topic of post-representative politics, the two most relevant cases are Podemos and M5S. Despite their differences in terms of founding moments, the construction of their representative claim, and the type of political culture they express, they nevertheless exhibit some comparable aspects. In particular, both parties can be traced back to movement parties (della Porta, Fernández, Kouki, \& Mosca, 2017; Kitschelt, 2006), i.e., networks of groups and individuals who share an identity and pursue social transformation objectives that hybridise with the organised forms of seeking electoral consensus (and power) specific to the parties, implementing a series of participation repertoires which emerge from traditional party procedures, even when they manage to gain access to government positions. As with mainstream parties, personalised leadership is decisive for movement parties, contributing and defining not only their organizational structure, but their very nature. If, in fact, the development of these parties falls within the scope of post-bureaucratic electoral parties, their form of leadership sits in a continuum, the two ends of which are forms of charismatic leadership, from a neo-patrimonial character up to the opposite extreme of movement parties that privilege assembly forms of horizontality from below in the role of spokesman (Kitschelt, 2006 , p. 281). With Podemos and M5S, the role of personalised leadership is a unifying trait, albeit for M5S it passed from a phase of the leader-centred party based around Beppe Grillo to fragmentation of the leadership itself, with a leader-guarantor (Grillo), a leader-creatorowner (Casaleggio, father, and later son), and the leader in public office (Di Maio), even without institutionalising the party. Despite the different development trajectories, both parties can be traced back to the 'movement digital party,' not only for the forms of disintermediation made possible by the internet, but also for introducing digital platforms to encourage participatory and decision-making processes. This is particularly true for M5S' adoption of the Rousseau Platform (owned by the Rousseau Association directed by Davide Casaleggio) and Podemos' use of Loomio as an open-source platform. We want to highlight that we use the term 'platform' in connection with a movement party, as a specific development of a party subtype that associates the identity and organizational characteristics of the movement party with the digital platform proper of a connective party (Bennett, Segerberg, \& Knüpfer, 2018). It is correct 
to remember, however, that the concept of platform has been used in different ways, in reference to:

(a) the new frontiers of digital capitalism (Srnicek, 2017) as well as the new (and sometimes disturbing) working methods coordinated by algorithms; (b) digital participation architectures, whether they are those adopted in open government procedures or whether they are used as support for deliberative processes; (c) new forms of political organization, as in the case of the digital parties; and (d) the digital reorganization of the state. (De Blasio \& Sorice, 2019, p. 5727)

Here we refer to the concept of platform as new form of political organization. Alongside the organizational dimension, the most significant divergences between the two digital movement parties (M5S and Podemos) concern their relationship with political identity and their specific version of populism. In this sense, Podemos is part of the new left parties against austerity, with a populist political strategy (that does not mean it can sic et simpliciter be defined a populist party) and a platform of policies attributable to the new radical left (Damiani, 2020; della Porta et al., 2017). In the case of M5S, the change in the party has undergone various stages of development, from its origins as environmentalist movement parties to becoming a 'pure' populist anti-parties party (Tarchi, 2015). Unlike the other populist and antiestablishment parties found in France, Spain, and Italy, M5S is the expression of 'civic populism,' a non-party party that moves in an openly post-representative political dimension. It takes to extremes the power of control, veto, and judgement proper to monitory democracy and counter-democracy, and as such radically overcomes the distinction between the elite and the people by portraying the 'people entering the institutions.'

Observing the new anti-establishment parties found in France, Spain, and Italy from an organizational and identity point of view, different configurations can be identified as developing between populist parties of the new radical right and digital populist movement parties. Nevertheless, these organizations share the same opposition to mainstream parties and also the central role of leadership in defining the political strategy and political identity of the party.

\section{Digital, Platform, and Networked Parties}

Over the past few years, a broad discussion has developed on the emergence of digital parties or platform parties; on the other hand, the same uncertainty about the use of the two (sometimes overlapping) terms highlights the complexity of the matter. Paolo Gerbaudo (2019) made use of the expression "digital party," also identifying the fundamental characteristics of its organizational pattern; from a different perspective, however, Marco Deseriis (2020) argues for the existence of two different models of platform party. The first one, which is essentially in continuity (although partial) with the parties that preceded it and which innovates through the use of digital technologies for participation; and the second one, appropriately defined as a "networked party", would present the following characteristics: non-exclusive membership, decentralization, leadership function, a bottom-up division of labour, collective agenda setting, hybrid participation, and scalable deliberation (Deseriis, 2020, p. 907).

The relationships between digital technologies for participation and organizational methods constitute a non-secondary aspect in the analysis on the transformation of parties. There are many political parties of different orientations which adopt platforms of democratic participation; significantly, however, the wealth of possibilities for online deliberation remains confined to a few exceptions. It is no coincidence that even the "networked party" model, as described by Deseriis (2020), finds in the "scalable deliberation" one of its qualifying aspects, but, nevertheless, it is quite well applied in marginal political formations, albeit culturally and socially significant. Experiences as the X-Party (which significantly define themselves as a "método para el control ciudadano de las instituciones," that is, a method for the citizens' control of the institutions; Partido $X$, n.d.) and some national groups framed within the Pirate Parties (namely German, Icelandic, and Swedish) appear very interesting from the researchers' perspective for their connection with the social movements' networks and their capacity to mobilise people through the digital ecosystem. At the same time, they do not have the same political impact as parties such as Podemos in Spain or Five Star Movement in Italy.

The conceptual clash between 'platform/digital party' and 'networked party' is based upon several keywords but it finds a point of clear distinction in the role of leadership and in the two oppositional models of involvement (plebiscitarianism vs collective agenda setting). The differences between a platform party and a networked party, as defined by Deseriis (2020, p. 908) are presented in Table 1.

In other works (see, for example, De Blasio \& Sorice, 2020) platform parties are studied as the outcome of a participatory logic even if they emerge as results of the hyper-representation phenomena. In essence, platform parties use technology as an organizational mode and a structural architecture (of a stratarchical type), but only at a secondary level are the participatory platforms used for policy-making procedures and to increase participatory (and scalable) forms of deliberation.

In Figure 1 we have tried to highlight the characteristics of the three party models: from the 'classic' one, the mass integration party as it developed mainly though not exclusively in the area of socialist tradition, to the platform party up to the variant represented by the networked party. According to Marco Deseriis, networked parties: 
Table 1. The keywords of platform party and networked party.

\begin{tabular}{ll}
\hline Platform Party & Networked Party \\
\hline Membership growth & Non-exclusive membership \\
Delocalization & Decentralization \\
Hyper-leadership & Leadership function \\
Superbase & Bottom-up division of labour \\
Plebiscitarianism & Collective agenda setting \\
Disintermediation & Hybrid participation \\
Distributed centralization & Scalable deliberation \\
\hline
\end{tabular}

Source: Deseriis (2020, p. 908).

Advance a model of digital party that leverages the decentralized affordances of the Internet to make the party line (and the relative division of labor) emerge from the network itself.... whereas the network form is by its very nature flexible, open ended, and receptive to the inputs that come from the social body, the party form is hierarchical, structured, partisan, and thus less permeable to the heterogeneity of the social. Whereas platform parties have solved this tension by delegating to their leaders the task of symbolizing the unity of the party, networked parties have bet on the capacity of networks to display emergent and self-organizing properties. (Deseriis, 2020, p. 913)

Both the platform party and the networked party can claim commonality with social movements and their democratic practices of communication. We have to underline, however, that the common place idea, here is that the movements would always be horizontal, without a hierarchical structure and without a leader, by virtue of the fact that they would borrow not only the dynamics of transmitting messages but also the modalities of the adoption of decisions. Following the influential study of Donatella della Porta and Dieter Rucht (2013), it can be useful to remember that in many cases the collective dimension of the protest is organised and staged by an elite group of activists. In our opinion, it is important to underline the difference between the movement parties (della Porta et al., 2017) and direct social action (Bosi \& Zamponi, 2019). If the first ones can constitute the background of some platform parties, there is no evidence that the second can represent the source for networked parties.

The studies on platform parties and on its variant of networked parties are the result of a long reflection on the transformation of the political parties, as we have explained in Sections 1 and 2. In particular, we would like to underline that the rhetoric of participation (the so-called "participationism," see Sorice, 2019) has always accompanied the emergence of new organizational forms of

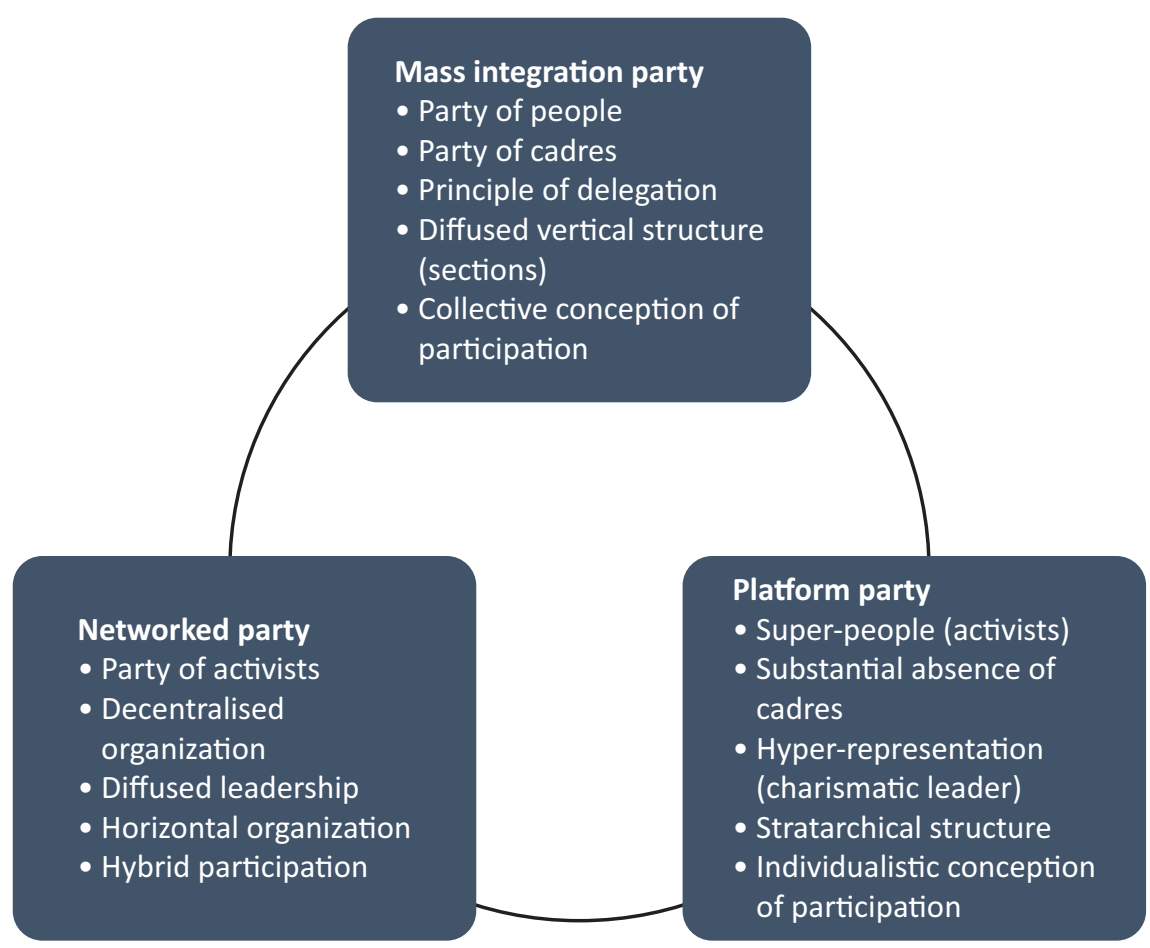

Figure 1. Characteristics of the mass party, platform party, and networked party. 
politics, although such rhetoric has been very often reduced to a generic 'openness to society' and programmatically refuses an internal organization based on deliberative and participatory logics. At this stage, the use of a really scalable deliberative practice could constitute an important element of newness in the parties rooted in the use of digital tools and, in many cases, fully framed in the digital ecosystem. Technologies, indeed:

Respond efficiently to three different tendencies of contemporary politics. In fact, they can: a) influence the organizational models of participation; b) accelerate the processes of deconstruction of intermediary bodies; c) feed the perspective of liquid democracy (a really controversial concept, usually overlapping with that of "delegative democracy" - a merging of representative and direct democracy-based upon the use of digital platforms). (De Blasio \& Sorice, 2020, pp. 92-93)

\section{Digital Ecosystem, Political Parties, and the Transformation of Public Sphere}

In the three countries under examination (France, Italy, Spain), we observed the organization and use of digital tools of parties of different political spectrum. In particular, we investigated the cases of La France Insoumise and La République en Marche (LaREM) in France, Podemos and Vox in Spain, and Five Star Movement and the League in Italy.

The first element to underline is the existence, in some cases, of co-ordinated digital actions, not organised around a participatory platform, that constitute a minority in the total number of technologies employed (except for the cases of Podemos in Spain and Five Star Movement in Italy). The digital tools are usually functional to mobilisation practices and work essentially as elements of support for political communication. Podemos was over time transformed from a party-platform to a party that uses a platform, and this transformation is more evident since the party took responsibility in the national government. Vox presents a traditional organization and many digital tools are used, but they are basically focused on creating consensus and/or promoting mobilisation.

In France, the 'participatory programme' experiments launched by La France Insoumise move from the level of mobilisation to spaces where concrete proposals are developed, and active deliberation processes take place. La France Insoumise, in any regard, cannot be defined as a platform party: it merges together a territorial organization with the use of digital tools. In particular, its 'Platform of Action' is a tool for policy proposal and political debate. The platform gives people the chance to manage their personal agenda and opens a space of engagement for the activist to whom it also offers the possibility to check the eventual action groups with which they are registered. There are also data on current and past initiatives as well as all the reports of the activities being organised. The platform, however, does not present a decision-making space in which participants can vote on programmes; in this aspect, it is very different from the use that the Five Star Movement (in Italy) makes of its platform (Rousseau), which instead presents spaces for the proposal of and voting on specific policies or on organizational aspects of the party's life. From this perspective, if the Five Star Movement can be placed, with some caution, among the "platform parties" (see Mosca, 2018, who states that Five Star Movement should be framed in the area of the "technopopulist parties," and De Blasio \& Sorice, 2018), La France Insoumise is a cross between an updated re-edition of the mass integration parties and the 'networked party.' The movement-party LaREM (a renaming of the En Marche movement launched by Emmanuel Macron in 2016 for the Presidential Election of 2017) is another example of cross-over: it presents, in fact, an horizontal structure, strongly decentralised but, at the same time, with a strong leadership and without a specific digital platform of political decision making. The analysis of the LaREM's activists presented by Bruno Cautrès, Marc Lazar, Thierry Pech, and Thomas Vitiello (2019) provides a wealth of information on the 'marcheurs' and on the party's organization. The recent reorganization of the party's structure at the end of 2019 confirms the idea of a party horizontal in its organization, well rooted in the digital culture, but not proactive in the use of digital platforms. At the same time, it is useful to remember that LaREM has been using a platform-website based upon the 'NationBuilder Tool' (NationBuilder is a web architecture managed by Tectonica, https://www.tectonica.co, a company that uses a technopolitical approach to democracy; see also https://nationbuilder.com/network). It is a collaborative and flexible platform also used on different occasions by the Scottish National Party, the Women's Equality Party of the UK, the Belgian and Norwegian Green Parties, the UK Labour Party, and others.

Table 2 summarizes how the different analysed parties use digital tools. Table 3 shows the use of specific participatory platforms (Podemos' Participa, Five Star Movement's Rousseau, and La France Insoumise's Platform of Action).

In Italy, the League is a particular case of a party strongly present on social media, with a great capacity to activate people through the 'news engagement' technique (Giglietto, Valeriani, Righetti, \& Marino, 2019), but with a total absence of digital participation structures. From an organizational point of view, the Lega Nord party (Northern League then only Lega-Leaguesince 2018) is connected to a parallel movement, the League for Salvini Premier, founded in 2018, whose structures coincide with those of the party. This situation determines the online presence of two different websites (leganord.org and legaonline.it). At the beginning of 2020, Salvini's movement has put the old Northern League under controlled management, effectively de- 
Table 2. Use of digital tools.

\begin{tabular}{|c|c|c|c|c|c|c|}
\hline Country & Parties & $\begin{array}{c}\text { Policy } \\
\text { proposals }\end{array}$ & Mobilisation & $\begin{array}{l}\text { Policy } \\
\text { making }\end{array}$ & $\begin{array}{l}\text { Decision } \\
\text { making }\end{array}$ & $\begin{array}{c}\text { Organizational } \\
\text { tool }\end{array}$ \\
\hline \multirow[t]{2}{*}{ France } & La France Insoumise * & YES & YES & NO & NO & YES \\
\hline & LaREM & NO & YES & NO & NO & YES \\
\hline \multirow[t]{2}{*}{ Spain } & Podemos * & YES & YES & YES & YES & YES \\
\hline & Vox & NO & YES & NO & NO & Partly \\
\hline \multirow[t]{2}{*}{ Italy } & Five Star Movement * & YES & YES & YES & YES & YES \\
\hline & League & NO & YES & NO & NO & NO \\
\hline
\end{tabular}

Note: * Use of a participatory platform (see also Table 3 ).

Table 3. Characteristics of the participatory platforms used by La France Insoumise, Podemos, and the Five Star Movement.

\begin{tabular}{|c|c|c|c|c|c|c|}
\hline Parties and Platforms & $\begin{array}{l}\text { Space for } \\
\text { activists }\end{array}$ & $\begin{array}{c}\text { Policy } \\
\text { proposals }\end{array}$ & $\begin{array}{l}\text { Procedures for } \\
\text { policy making }\end{array}$ & $\begin{array}{c}\text { Deliberative } \\
\text { tools }\end{array}$ & $\begin{array}{l}\text { Organization } \\
\text { tools }\end{array}$ & $\begin{array}{l}\text { Is platform the only } \\
\text { organization tool? }\end{array}$ \\
\hline $\begin{array}{l}\text { La France Insoumise } \\
\text { Platform of Action }\end{array}$ & YES & YES & NO & NO & YES & NO \\
\hline $\begin{array}{l}\text { Podemos } \\
\text { Participa }\end{array}$ & YES & YES & YES & YES & YES & NO \\
\hline $\begin{array}{l}\text { Five Star Movement } \\
\text { Rousseau }\end{array}$ & YES & YES & YES & NO & YES & NO \\
\hline
\end{tabular}

creeing its end despite the fact that it continues to exist for issues related to legal problems.

The complex relationships between digital ecosystems and political parties bring about a transformation in the role of parties within the public sphere. The development of platform parties has highlighted the dynamics of fragmentation of representation and the emergence of forms of "direct representation" (De Blasio \& Sorice, 2019). In this context, the role of media ecosystems is of fundamental importance for: a) the legitimization of the hyper-leader as hyper-representative; b) building credibility of occasional forms of representation (which only in the context of the media-broadcasting and social media-take on significant social value); and c) the social diffusion of direct representation mechanisms (which exist only by virtue of an exchange activated in the first instance by the media and online political communities). The online public sphere, in fact very stratified, once again constitutes a space of conflict and, in many cases, of manipulation.

The transformation of political parties does not constitute-as is sometimes simplistically said-their dissolution; the emergence of platform/digital parties and/or networked parties and even hybrid aggregations are, if anything, evidence of the transformation of the same dynamics and procedures of political representation. The multiple forms of interaction between movements and parties, as well as the processes of repoliticization through movements, are other evidences of the transformations taking place. In this context, digital activism acts as a modality of reorganization of consensus, development of mobilization, and redefinition of the forms and modes of representation.

\section{Conflict of Interests}

The authors declare no conflict of interests.

\section{References}

Abedi, A. (2004). Anti-political establishment parties: A comparative analysis. London: Routledge.

Bennett, W. L., Segerberg, A., \& Knüpfer, C. B. (2018). The democratic interface: Technology, political organization, and diverging patterns of electoral representation. Information, Communication \& Society, 21(11), 1655-1680.

Blondel, J., \& Thiébault, J. (2010). Political leadership, parties and citizens: The personalisation of leadership. London: Routledge.

Bobbio, N. (1984). Il futuro della democrazia [The future of democracy]. Torino: Einaudi.

Bordignon, F., \& Ceccarini, L. (2015). The Five-Star Movement: A hybrid actor in the net of state institutions. Journal of Modern Italian Studies, 20(4), 454-473.

Bornschier, S. (2010). Cleavage politics and the populist right: The new cultural conflict in Western Europe. Philadelphia, PA: Temple University Press. 
Bosi, L., \& Zamponi, L. (2019). Resistere alla crisi. I percorsi dell'azione sociale diretta [Resisting the crisis. The paths of direct social action]. Bologna: II Mulino.

Caramani, D. (2017). Will versus reason: The populist and technocratic forms of political representation and their critique to party government. American Political Science Review, 44(3), 303-306.

Cautrès, B., Lazar, M., Pech, T., \& Vitiello, T. (2019). La République en Marche: Anatomie d'un mouvement [La République en Marche. Anatomy of a movement]. Paris: SciencesPo. Retrieved from https:// spire.sciencespo.fr/hdl:/2441/7jevg6gne390e9fslg2 gg9sde8/resources/2018-10-cautres-la-republiqueen-marche.pdf

Ceccarini, L., \& Bordignon, F. (2016). The five stars continue to shine: The consolidation of Grillo's 'movement party' in Italy. Contemporary Italian Politics, 8(2), 131-159.

Cohen, J., \& Arato, A. (1992). Civil society and political theory. Cambridge, MA: MIT Press.

Crouch, C. (2003). Post-democracy. Oxford: Polity Press.

Dalton, R. J. (2004). Democratic challenges, democratic choices: The erosion of political support in advanced industrial democracies. Oxford: Oxford University Press.

Dalton, R. J., Farrell, D. M., \& McAllister, I. (2011). Political parties and democratic linkage: How parties organize democracy. Oxford: Oxford University Press.

Dalton, R. J., \& Wattenberg, M. P. (Eds.). (2000). Parties without partisans: Political change in advanced industrial democracies. Oxford: Oxford University Press.

Damiani, M. (2020). Populist radical left parties in Western Europe. London: Routledge.

De Blasio, E., \& Sorice, M. (2018). Populism between direct democracy and the technological myth. Palgrave Communications, 4(1), 1-11.

De Blasio, E., \& Sorice, M. (2019). E-democracy and digital activism: From divergent paths toward a new frame. International Journal of Communication, 13, 5715-5733.

De Blasio, E., \& Sorice, M. (2020). Spaces of struggle: Socialism and neoliberalism with a human face among digital parties and online movements in Europe. tripleC: Communication, Capitalism \& Critique, 18(1), 84-100.

della Porta, D. (2013). Can democracy be saved?: Participation, deliberation and social movements. Cambridge: Polity Press.

della Porta, D., Fernández, J., Kouki, H., \& Mosca, L. (2017). Movement parties against austerity. Cambridge: Polity Press.

della Porta, D., \& Rucht, D. (2013). Meeting democracy: Power and deliberation in global justice movements. Cambridge: Cambridge University Press.

Deseriis, M. (2020). Two variants of the digital party: The platform party and the networked party. Partecipazione e Conflitto, 13(1), 896-917.

Diehl, P. (2019). Twisting representation. In C. de la Torre
(Ed.), Routledge handbook of global populism (pp. 129-143). London: Routledge.

Garzia, D. (2014). Personalization of politics and electoral change. Basingstoke: Palgrave Macmillan.

Gauja, A. (2017). Party reform: The causes, challenges, and consequences of organizational change. Oxford: Oxford University Press.

Gerbaudo, P. (2019). The digital party: Political organisation and online democracy. London: Pluto Press.

Giglietto, F., Valeriani, A., Righetti, N., \& Marino, G. (2019). Diverging patterns of interaction around news on social media: Insularity and partisanship during the 2018 Italian election campaign. Information, Communication and Society, 22(11), 1610-1629.

Green, J. E. (2010). The eyes of the people: Democracy in an age of spectatorship. Oxford: Oxford University Press.

Gunther, R., \& Diamond, L. (2001). Types and functions of parties. In L. Diamond \& R. Gunther (Eds.), Political party and democracy (pp. 3-39). London and Baltimore, MD: Johns Hopkins University Press.

Habermas, J. (1990). Strukturwandel der Öffentlichkeit. Untersuchungen zu einer Kategorie der bürgerlichen Gesellschaft [Structural change of the public. Investigations into a category of civil society]. Frankfurt: Suhrkamp.

Higley, J., \& Pakulski, J. (2008). Towards leader democracy? In P. t'Hart \& J. Uhr (Eds.), Public leadership: Perspectives and practices (pp. 45-54). Canberra: Australian National University Press.

Ignazi, P. (2017). Party and democracy: The uneven road to party legitimacy. Oxford: Oxford University Press.

Karvonen, L. (2010). The personalisation of politics: A study of parliamentary democracies. Colchester: ECPR Press.

Katz, R. S., \& Mair, P. (2002). The ascendancy of the party in public office: Party organizational change in twentieth-century democracies. In R. Gunther, J. R. Montero, \& J. J. Linz (Eds.), Political parties: Old concepts and new challenges (pp. 113-135). Oxford: Oxford University Press.

Katz, R. S., \& Mair, P. (2018). Democracy and the cartelization of political parties. Oxford: Oxford University Press.

Keane, J. (2009). The life and death of democracy. London: Simon \& Schuster.

Keane, J. (2013). Democracy and media decadence. Cambridge: Cambridge University Press.

Kitschelt, H. (2006). Movement parties. In R. Katz \& W. Crotty (Eds.), Handbook of party politics (pp. 278-291). London: Sage.

Körösényi, A. (2005). Political representation in leader democracy. Government and Opposition, 40(3), 358-378.

Körösényi, A., \& Pakulski, J. (2012). Toward leader democracy. London: Anthem Press.

Kriesi, H-P., Grande, E., Dolezal, M., Helbling, M., Höglinger, D., Hutter, S., \& Wüest, B. (Eds.). (2012). 
Political conflict in Western Europe. Cambridge: Cambridge University Press.

Kriesi, H-P., \& Hutter, S. (2019). European party politics in times of crisis. Cambridge: Cambridge University Press.

Kriesi, H-P., \& Pappas, T. S. (Eds.). (2015). European populism in the shadow of the great recession. Colchester: ECPR Press.

Levitsky, S., \& Ziblatt, D. (2018). How democracies die. New York, NY: Crown Publishing.

Mair, P. (2002). Populist democracy vs party democracy. In Y. Meny \& Y. Surel (Eds.), Democracies and the populist challenge (pp. 81-98). Basingstoke: Palgrave Macmillan.

Mair, P. (2013). Ruling the void: The hollowing of Western Democracy. London: Verso.

Manin, B. (1997). The principles of representative government. Cambridge: Cambridge University Press.

McAllister, I. (2007). The personalization of politics. In R. J. Dalton \& H. D. Klingemann (Eds.), Oxford handbook of political behavior (pp. 571-588). Oxford: Oxford University Press.

Meny, Y., \& Surel, Y. (2002). The constitutive ambiguity of populism. In Y. Meny \& Y. Surel (Eds.), Democracies and the populist challenge (pp. 1-21). Basingstoke: Palgrave Macmillan.

Mosca, L. (2020). Democratic vision and online participatory spaces in the Italian Movimento 5 Stelle. Acta Politica, 55, 1-18.

Merkel, W. (2004). Embedded and defective democracies. Democratization, 11(5), 33-58.

Merkel, W. (2014). Is there a crisis of democracy? Democratic Theory, 1(2), 11-25.

Merkel, W. (2018). Challenges or crisis of democracy. In W. Merkel \& S. Kneip (Eds.), Democracy and crisis: Challenge in turbulent times (pp. 1-28). New York, NY: Springer.

Mudde, C. (1996). The paradox of the anti-party party: Insights from the extreme right. Party Politics, 2(2), 265-276.

Müller, J. W. (2016). What is populism? Philadelphia, PA: University of Pennsylvania Press.

Musella, F. (2018). Political leaders beyond party politics. Basingstoke: Palgrave Macmillan.

Pakulski, J. (2012). The Weberian foundations of modern elite theory and democratic elitism. Historical Social Research, 1(139), 38-56.

Pappas, T. S. (2019). Populism and liberal democracy: A comparative and theoretical analysis. Oxford: Oxford University Press.

Partido X. (n.d.). Homepage. Partido X. Retrieved from https://partidox.org

Pilet, J. B., \& Cross, W. (2015). Uncovering the politics of party leadership. In W. Cross \& J. B. Pilet (Eds.), The politics of party leadership: A cross-national perspective (pp. 1-11). Oxford: Oxford University Press.

Poguntke, T. (2002). Parties without firm social roots? Party organisational linkage (Working Paper No. 13). Keele: Keele European Parties Research Unit.
Poguntke, T., \& Webb, P. (2005). The presidentialization of politics: A comparative study of modern democracies. Oxford: Oxford University Press.

Rahat, G., \& Kenig, O. (2018). From party politics to personalised politics? Party change and political personalization in democracy. Oxford: Oxford University Press.

Rahat, G., \& Sheafer, T. (2007). The personalization(s) of politics: Israel, 1949-2003. Political Communication, 24(1), 65-80.

Raniolo, F., \& Morlino, L. (2017). The impact of the economic crisis on South European democracies. Basingstoke: Palgrave McMillan.

Roberts, K. M. (2015). Populism, political mobilization, and crises of political representation. In C. de la Torre (Ed.), The promise and perils of populism: Global perspectives (pp. 140-158). Lexington, KY: The University Press of Kentucky.

Rosanvallon, P. (2008). Counter-democracy: Politics in an age of distrust. Cambridge: Cambridge University Press.

Runciman, D. (2018). How democracy ends. London: Profile Books.

Saward, M. (2010). The representative claim. Oxford: Oxford University Press.

Schedler, A. (1996). Anti-political-establishment parties. Party Politics, 2(3), 291-312.

Schumpeter, J. A. (2003). Capitalism, socialism and democracy. London: Routledge.

Sorice, M. (2019). Partecipazione democratica. Teorie e problemi [Democratic participation. Theories and Problems]. Milan: Mondadori.

Tarchi, M. (2015). Italia populista. Dal qualunquismo a Beppe Grillo [Populist Italy. From "qualunquismo" to Beppe Grillo]. Bologna: II Mulino.

Tormey, S. (2015). The end of representative politics. Cambridge: Cambridge Polity Press.

Urbinati, N. (2019). Me the people: How populism transforms democracy. Cambridge, MA: Harvard University Press.

van Biezen, I. (2004). Political parties as public utilities. Party Politics, 10(6), 701-722.

van Biezen, I., Mair, P., \& Poguntke, T. (2012). Going, going,...gone? The decline of party membership in contemporary Europe. European Journal of Political Research, 51(1), 24-56.

Viviani, L. (2017). A political sociology of populism and leadership. Società Mutamento Politica, 8(15), 279-303.

Viviani, L. (2019). Populist anti-party parties. In P. Blokker \& M. Anselmi (Eds.), Multiple populisms: Italy as democracy's mirror (pp. 106-123). London: Routledge.

Webb, P., Farrell, D. M., \& Holliday, I. (Eds.). (2002). Political parties in advanced industrial democracies. Oxford: Oxford University Press.

White, J., \& Ypi, L. (2016). The meaning of partisanship. Oxford: Oxford University Press. 


\section{About the Authors}

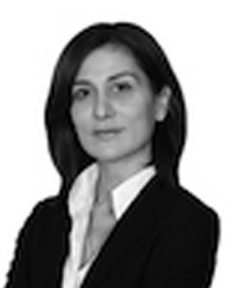

Emiliana De Blasio teaches Media Sociology, Gender Politics and Open Government at the Department of Political Sciences of LUISS University of Rome, Italy. She is the Deputy Director of the Luiss Centre for Conflict and Participation Studies and Invited Professor at Gregorian University. Her research activities focus on the digital ecosystem, the transformation of the public sphere, the relationship between gender and party organisation, e-democracy, open government and the impact of technologies on populisms.

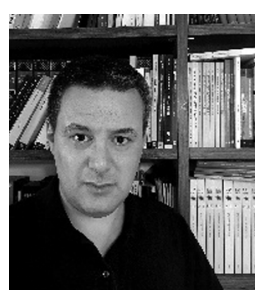

Lorenzo Viviani is Associate Professor of Political Sociology at the Department of Political Science, University of Pisa, Italy. He is the Secretary of the Political Sociology Section of AIS (Italian Sociological Association). His research focuses on the sociology of political parties, political leadership, democracy, and populism. Among his most recent publications there are books, chapters, and articles on the growth of populism in post-representative democracy with particular reference to the sociological perspective of plebiscitarian leadership. 